Науковий вісник : Державне управління № 4(10) 2021

УДК 005:351/354(438)+351.861

Коженовські Лсшек

ORCID iD 0000-0002-1866-3027

E-mail: lfk@interia.pl

Литвиновський Евген

ORCID iD 0000-0003-2127-8354

E-mail: doklytvynovsky@ukr.net

\title{
ІНФОРМАЦІЯ - ВАЖІЛЬ АНТИКРИЗОВОГО МЕНЕДЖМЕНТУ РЕСПУБЛІКИ ПОЛЬЩА
}

\author{
https://doi.org/10.33269/2618-0065-2021-4(10)-71-94
}

Анотація. Вимогами сучасності для сталого функціонування глобального суспільства в умовах надзвичайних викликів до його стійкості є проведення методологічних та науково-прикладних досліджень 3 проблематики цивільної безпеки, вивчення кращих практик антикризового менеджменту країн Свропи. Також науковим завданням $\epsilon$ теоретичне обгрунтування складових механізму державного управління сферою цивільної безпеки та їх характеристик. На основі аналізу механізму державного антикризового управління республіки Польща гіпотетично визначено інформацію як центральний (базовий) його важіль, обгрунтовано ії значущі характеристики. Методами дослідження були метод компаративного аналізу, контентаналізу, гіпотетичний, метод інтерв'ювання експертів. На основі аналізу попередніх наукових розвідок визначено, що такі структурні елементи механізму державного управління як політики, важіль, інструменти, зокрема в управлінні сферою цивільної безпеки, не знайшли свого місця, часом їх ототожнюють, а здебільшого лише похідно про них згадують. Зазначені дослідження $є$ теоретичною базою підтвердження гіпотези, що інформація $\epsilon$ основою прийняття державних управлінських рішень, невід'ємною частиною системи, метою якої є зменшення стану невизначеності іiі функціонування, не лише міждисциплінарним терміном, який суперечить невідомому, а й ключовим фактором (важелем державного управління) національної безпеки. Обіг інформації є підгрунтям належного функціонування системи антикризового управління Республіки Польща (далі - РП).

Аналіз системи антикризового менеджменту РП свідчить, що діяльність органів управління спрямована на організацію і підтримку всіх можливих систем комунікації - інформаційних, транспортних, логістичних тощо. Чим вищий рівень управління, тим важливішим $є$ фактор координації окремих видів діяльності. Ця координація органів управління (сил) антикризового менеджменту заснована на базі отримання (надання) повідомлень (інформації) з наявних сил і засобів та проведених заходів суб'єкта системи нижнього рівня управління та повідомлень із запитом необхідних сил i засобів з вищих рівнів управління. Також значна увага приділяється системі 
моніторингу визначених загроз. Пропонується замість поняття «моніторинг» ввести «контролінг», в основі якого лежить збір, обробка, перевірка, стандартизація відповідної інформації (повідомлення) про стан (загрозу, ризик) об'єкта захисту. Визначено, що для упорядкування ієрархічної інформації та обробки даних у системі антикризового менеджменту РП, підтримання ефективного інформаційного потоку стандартизованих даних (збір мінімального обсягу даних, доповнення (за необхідності) їх додатковою інформацією та представлення у вигляді звіту (початкового, корегуючого, заключного) про ситуацію, функціонує інформаційноаналітична система «Central Reporting Application». Зроблено висновок, що інформація - це зміст, який передається повідомленням, що надає можливість зрозуміти сенс даних і взаємозв'язок між ними, точка опори системи (механізму) державного управління антикризового менеджменту, відповідно до характеристик якої визначається ефективність діяльності його комунікаційної складової зокрема та всієї системи антикризового менеджменту загалом. Визначено значущі характеристики інформації, серед яких: актуальність, цінність, своєчасність, обгрунтованість, правдивість або істинність (хибність), суб'єктність (суб'єктивність), об'єктивність, первинність (вторинність), корисність, повнота, точність, гнучкість, достовірність, достатність, унікальність, однозначність. Напрямом подальшого дослідження $€$ вивчення практичних кейсів щодо функціонування інформаційно-аналітичних систем антикризового менеджменту країн Європи 3 визначення значущих характеристик інформаційних потоків, що в них обробляються.

Ключові слова: цивільна безпека, механізм державного управління, система антикризового менеджменту Республіки Польща, інформація, важіль.

\section{Постановка проблеми. В умовах перманентного} удосконалення системи державного управління в Україні, визначення стратегічного напряму поступу країни в Європейський Союз залишається науковим завданням вивчення кращих практик його членів у різних сферах суспільного життя, у тому числі у сфері цивільної безпеки.

У західній науці та практиці, зазначає Д. Тихомиров, «поняття цивільна безпека не має сталого нормативноправового визначення та наукового тлумачення, визнається поняттям 3 мінливим змістом, який певним чином конкретизується в процесі діяльності суб'єктів, предметом якої і є безпека. Вітчизняне розуміння цивільної безпеки формується переважно на перехресті понять національна безпека, громадська та публічна безпека, цивільний захист та інших споріднених понять...» [1, с. 398]. Це актуалізує необхідність 
проведення методологічних досліджень 3 об’єктноорієнтованого аналізу сфери цивільної безпеки загалом.

Крім того, функціонування суспільства в умовах надзвичайних викликів до його стійкості привертає увагу до теоретико-прикладних досліджень проблематики державного управління цивільною безпекою держави, вивченню кращих практик державного антикризового управління в світовому просторі. Саме антикризового управління (позиція Є. Литвиновського) бо, як ми наголошували у попередній публікації, наприклад в Республіці Польща [2], зосереджується увага саме на питаннях запобігання, мінімазіції ризиків виникнення небезпек, моніторингу стану безпеки об'єктів захисту, тобто на проблематиці антикризового управління (запобігання, а не реагування на кризу). У дослідженнях вітчизняних науковців більше виділяється проблематика управління в умовах виникнення надзвичайних ситуацій, наприклад у [3; 4].

Взагалі усталеним розумінням механізму державного управління цивільним захистом України, враховуючи системний підхід до визначення поняття «механізм державного управління» $[5,6], \epsilon$ таке : «це сукупність взаємообумовлених, взаємодіючих органів державного управління та вищих посадових осіб держави, яка в межах чинного законодавства та із залученням наявного у іiі розпорядженні потенціалу держави (матеріального, фінансового, інтелектуального та духовного) здійснює розробку й реалізацію владних, регулюючих, координуючих, контролюючих та нормативних державноуправлінських впливів (рімень) на об'єкти безпеки 3 метою прогнозування, своєчасного виявлення, запобігання та нейтралізації загроз сталому розвитку вищезазначених об'єктів, передусім життєво важливим національним інтересам» [7; 8].

Як показує аналіз досліджень [9], у тому числі з проблематики державного управління цивільним захистом, наприклад $[10 ; 11$; 14], загальновизнаними елементами структури механізму державного управління загалом та сферою цивільного захисту зокрема, є методи, важелі, інструменти, політика, правове, нормативне та інформаційне забезпечення. Однак, якщо питання правового, нормативного та інформаційного 
забезпечення цивільним захистом можна знайти в науковому дискурсі [10-18], то визначення та обгрунтування окремих політик, інструментів, важелів, методів державного управління системою цивільного захисту не знайшли свого місця в наукових дослідженнях: часом їх ототожнюють, а здебільшого лише похідно про них згадують. Їх «...опис має досить загальне спрямування;...не простежується чіткий взаємозв'язок між визначенням механізму державного управління та його структурою» [18].

На жаль, можна констатувати, що протягом 30-річчя існування науки державного управління деякі структурні елементи механізму державного управління так і не отримали сталих визначень, опису їх специфіки, а такі структурні компоненти механізму як правове, нормативне, інформаційне забезпечення визначаються як окремі механізми комплексного механізму державного управління. [6, 10]. Це $є$ похідною проблемою розвитку методології науки публічного управління та адміністрування, зокрема у сфері цивільної безпеки.

Отже, визначення політик, інструментів, важелів механізму державного управління цивільною безпекою України, антикризового менеджменту Польщі є предметним полем для багатьох досліджень.

Мета статті. В рамках нашого компаративного дослідження ми продовжуємо публікацію його результатів. У цій публікації, на основі аналізу механізму державного антикризового управління Республіки Польща, гіпотетично визначаємо інформацію як його центральний (базовий) важіль (С. Литвиновський), розкриваємо iї основні характеристики (Л. Коженовські).

Методи дослідження. Загальним методом дослідження $є$ метод компаративного аналізу систем антикризового менеджменту країн Свропи. Для аналізу попередніх досліджень 3 визначеної проблематики застосовується метод контентаналізу дотичних досліджень. Гіпотетичний метод. Висунуто наукове припущення щодо визначення інформації як базового важеля у структурі механізму державного управління цивільною безпекою, що потребує перевірки та теоретичного 
обгрунтування. Для експертного визначення місця i характеристики інформації в системі антикризового менеджменту застосовується метод інтерв'ювання польських науковців.

Аналіз попередніх досліджень. Наукові дослідження проблематики механізмів державного управління сферою цивільного захисту, іiі складових проводили С. Андреєв, К. Белікова, П. Гаман, С. Майстро, О. Мельниченко, С. Потеряйко, О. Труш, Ю. Харламова [3; 7-15]. Деякий аналіз цих досліджень здійснено при постановці проблеми дослідження.

Що ж до виокремленої нами проблематики, а саме визначення важелів державного управління сферою цивільної безпеки та «інформації» як центрального (базисного) важеля, а тим більше системи антикризового менеджменту РП, то зазначене серед доступних досліджень не виявлено. Проблематики адекватності, повноти, оперативності та корисності інформації тим чи іншим чином торкаються науковці чи не в кожному дослідженні, що присвячено державному управлінню та прийняттю управлінських рішень. Так аналіз бази даних Національної бібліотеки імені В. I. Вернадського [9] за ключовими словами «цивільний захист», «механізм державного управління» «інформація» свідчить, що поняття «інформація» зустрічається в більшості з них.

Дотичними дослідженнями можна вважати дослідження К. Белікової (О. Барило).

У темі статті К. Белікової [19] у прямій постановці інформація визначається як складова системи державного управління у надзвичайних ситуаціях. Однак в основному тексті мова йдеться про необхідність інформаційноаналітичного забезпечення як процесу одержання, опрацювання, зберігання та подання інформації, а в іншій статті [10] вона визначає цей процес окремим механізмом інформаційно-аналітичним.

3 точки зору вагомості інформації в системі управління й обгрунтування нашої гіпотези щодо визначення інформації базисним важелем, то теоретичним підгрунтям $є$ позиція авторки, яка спираючись на логіко-семантичний підхід, 
запропонований Д. Біленською [цит. за 20] у своїй дисертації визначає:

інформація є основою прийняття державних управлінських рішень [20,с. 101];

інформація - знання, яке використовується для орієнтування в ситуації і призначене для активних дій [цит. за 20, с. 127].

прийняття аргументованих рішень вимагає забезпечення керівників усіх рівнів управління вірогідною, своєчасною та достатньою інформацією...Доречна інформація має важливе значення для результативної діяльності [20, с. 144].

принцип придатності інформації до використання. Будь-яка інформація повинна бути певним чином структурована [20, с. 144].

Важливим для нас, є думка Г. Ситника, який визначив, що модель прийняття управлінського рішення на основі функціонування інформаційного механізму являє собою алгоритм узагальнення інформації, що надходить до суб'єктів [21, c. 282].

Н. Клименко визначає, що серед ключових показників, які впливають на безпеку функціонування системи державного управління в надзвичайних ситуаціях $є$ інформація. Зростання рівня невизначеності інформації приводить до зростання ризику прийняття неадекватного рішення [цит. за 20, с. 145].

Виклад основного матеріалу. У сучасних умовах розвитку інформаційного суспільства інформація (О. Твердохліб) перетворилася на вихідний і кінцевий продукт праці - вона збирається, підлягає обробці та розповсюдженню; вона вже стала товаром, що продається i купується, а побудована на іiі основі інформаційна система $\epsilon$ спинним хребтом сучасного суспільства [41].

Процес управління, зазначає К. Белікова як діяльність об'єднаних у визначену систему суб єктів управління, полягає у роботі з інформацією [20, с. 121].

Законом України «Про інформацію» визначено: «інформація - будь-які відомості та/або дані, які можуть бути збережені на матеріальних носіях або в електронному вигляді»[22]. 
Н. Калюжна зауважує, що «управлінська інформація $є$ структурованими даними, застосування яких сприяє зменшенню невизначеності в систему управління, підвищення ступеню iї впорядкованості...» [цит. за 20, с. 145].

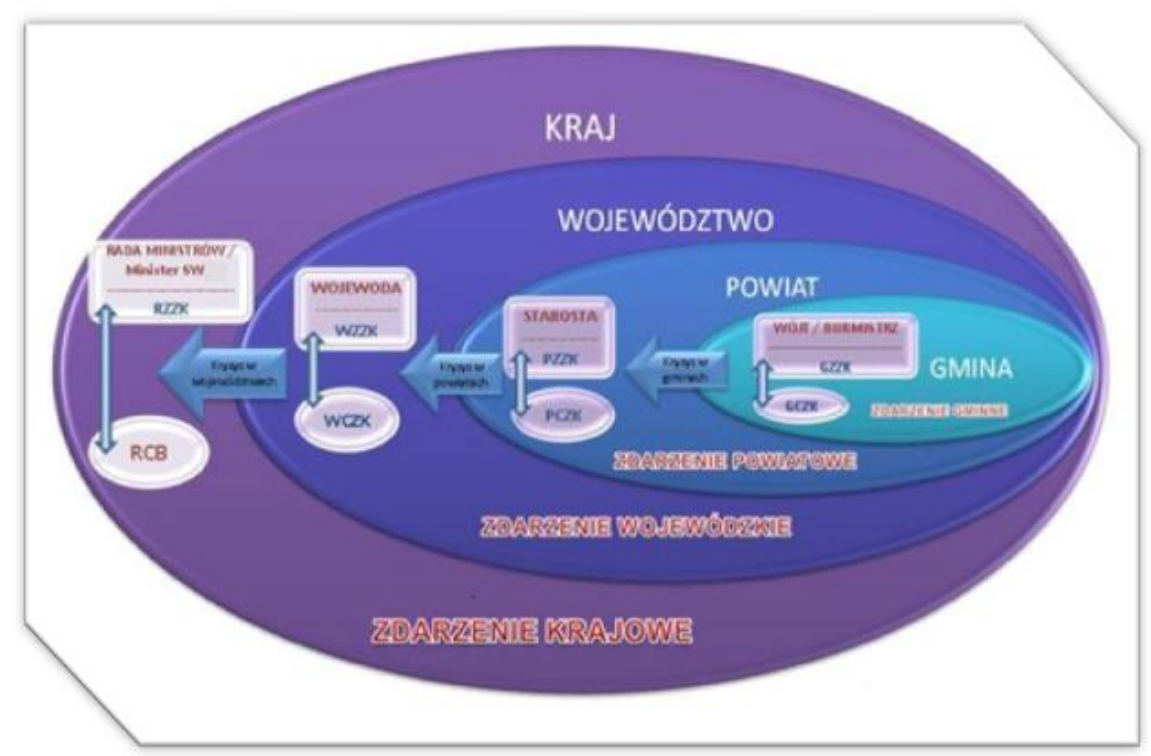

Рисунок 1 - Модель організації оповіщення та реагування на кризу (наведено оригінальною мовою)

Джерело : [23]

Аналіз системи антикризового менеджменту Республіки Польща, планів антикризового менеджменту мережі безпеки [2] свідчить, що діяльність органів управління спрямована на організацію і підтримку всіх можливих систем комунікації інформаційних, транспортних, логістичних тощо. А чим вищий рівень управління, тим важливішим $\epsilon$ фактор координації окремих видів діяльності [23]. Ця координація органів управління (сил) антикризового менеджменту (рис. 1) заснована на базі отримання (надання) повідомлень з наявних сил і засобів та проведених заходах суб'єкта системи нижнього рівня управління та повідомлень з запитом необхідних сил і засобів 3 вищих рівнів управління [24]. Також велика увага приділяється системі моніторингу визначених загроз. Моніторинг (від англ. «monitor») - це організований спосіб спостереження, зазвичай 
безперервного та тривалого, 3 використанням камери, відеореєстратора або вимірювальних приладів. «Моніторити» у значенні «слідувати, спостерігати, наглядати» (без використання камер) - це модне (перевживане) слово, але воно не було схвалено лінгвістами [25].

Для системи антикризового менеджменту РП краще застосовувати термін «контролінг» (Л. Коженовські), тобто перевірка того, чи досягаються цілі та чи відповідають характеристики об'єкта та реальної дії запланованим стандартам, програмам, бюджетам, орієнтирам тощо [26]. ISO 8402 описує контролінг як «вимірювання, тестування, оцінку або перевірку однієї чи кількох властивостей об'єкта та порівняння їх із вимогами, щоб визначити, чи відповідає кожна 3 цих властивостей » [27].

В основі зазначеного процесу (контролінгу) лежить збір, обробка, перевірка, стандартизація відповідної інформації (повідомлення) про стан (загрозу, ризик) об'єкту захисту.

Описуючи принцип інформаційного потоку в антикризовому управлінні Республіки Польща Матеуш Юргевич (Mateusz Jurgiewicz) визначає, що інформація :

основний компонент зв'язку між елементами множин окремих об'єктів.

невід'ємна частина системи, метою якої є зменшення стану невизначеності їі функціонування;

не лише міждисциплінарний термін, який суперечить невідомому, а й ключовий фактор (важіль державного управління - Литвиновський С.Ю.) національної безпеки;

Обіг інформації $\epsilon$ основою належного функціонування системи антикризового управління [23].

Аналіз рис. 1 свідчить, що в системі антикризового менеджменту РП чітко розрізняються рівні державного управління та потік інформації між ними. Водночас на кожному рівні існує організаційний підрозділ, відповідальний за антикризове управління. Завданням такого підрозділу $\epsilon$, насамперед, отримання інформації про загрози та їх оцінювання, постійний моніторинг (контролінг) цих загроз, а також оцінювання ризиків, прогнозування стану розвитку 
загроз у зоні, якій він підпадає, та використання цієї інформації для удосконалення планів антикризового управління.

Постійний моніторинг загроз, надсилання ієрархічної інформації та обробка даних потребувала створення відповідних інформаційних систем для системи антикризового менеджменту РП. Урядовим центром безпеки під час розгляду проблем, пов'язаних 3 потоком інформації в системі антикризового управління (2013) було розроблено відповідне програмне забезпечення (Central Reporting Application). Його завданням $є$ підтримання ефективного інформаційного потоку стандартизованих даних (збір мінімального обсягу даних, доповнення (за необхідності) їх додатковою інформацією та представлення у вигляді звіту (початкового, корегуючого, заключного) про ситуацію). Кожен із звітів складається 3 описової частини, стандартизованої частини (числові дані про масштаби загрози, потенційних жертв, кількість загроз тощо) та додатків. Діаграму інформаційного потоку в системі CAR ілюструє рис. 2:

Враховуючи зазначене вище, тлумачення поняття важіль «як засобу без якого не може бути будь-яка людська діяльність, яким можна надати дії, сприяти розвитку, пожвавите, підсилити діяльність..» або навпаки [28], інформація (повідомлення) є тим важелем в структурі механізму державного управління, без якого система антикризового менеджменту не може існувати. Інформація - точка опори системи (механізму) державного управління антикризового менеджменту, відповідно до характеристик якої визначається ефективність діяльності його комунікаційної складової зокрема та всієї системи антикризового менеджменту загалом. Розрив комунікації на одному рівні може призвести до зриву виконання завдань системи в цілому. Отже, $є$ необхідність розглянути характеристики інформації, визначити вимоги. Про це в подальшому йтиметься у статті за авторством Л. Коженовські (переклад 3 польської С. Литвиновського) 3 посиланнями на деяких польських науковців - фахівців кризового менеджменту, тим самим презентуючи їх думку із зазначеної проблематики. 
Науковий вісник : Державне управління № 4(10) 2021

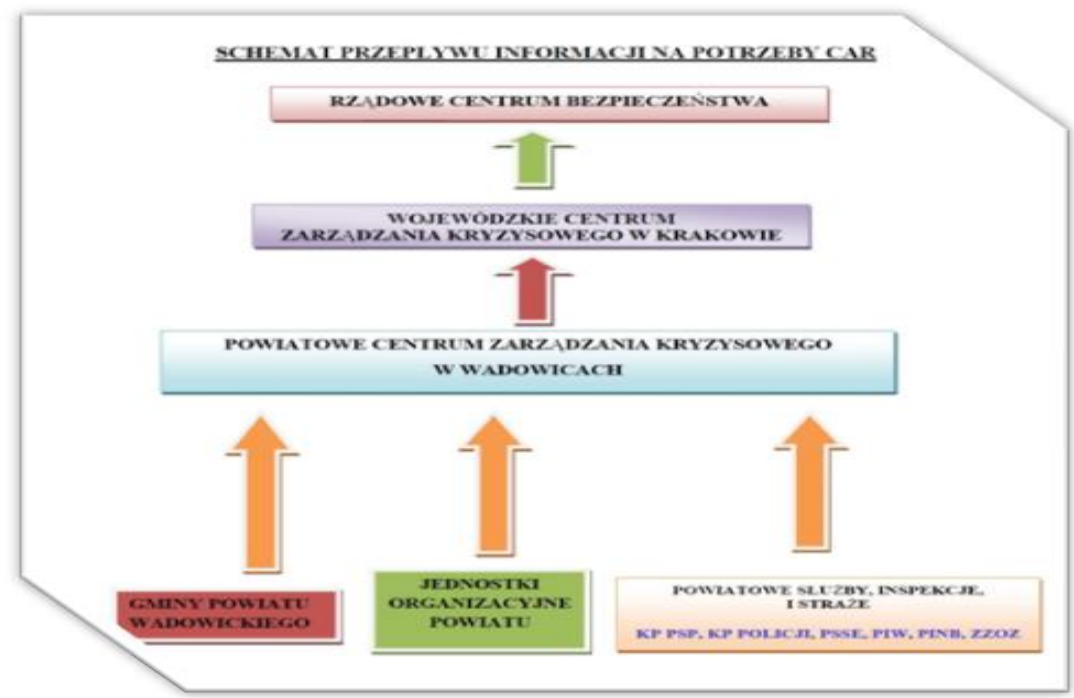

Рисунок 2 - Діаграма потоку інформації в програмному забезпеченні CAR (наведено орігінальною мовою).

Джерело: [23]

Отже, у процесі управління безпекою надзвичайно важливо пояснити та зрозуміти суть інформації (зображення, пояснення, повідомлення). Інформація є складним поняттям і належить до багатьох загальновживаних понять, які не мають однозначного визначення. Інформація дихотомічна i зустрічається: як відображення того, що існує в матеріальному сенсі; як фактор, що певною мірою визначає форму майбутніх речей $\mathrm{i}$ явищ (важливо для системи антикризового менеджменту при прогнозуванні майбутніх подій на основі інформації про ризики ïх виникнення).

Філософи зазвичай розуміють інформацію як відображення різноманітності, що характеризує об'єкт, подію, процес чи явище, що розглядається. Творець кібернетики Норберт Вінер стверджує, що «інформація — це назва вмісту, взятого із зовнішнього світу, коли ми підлаштовуємо до нього свої органи чуття» [цит. за 29].

У теорії інформації, інформація є мірою невизначеності настання певної події серед кінцевої множини можливих подій [30], що надає можливість дійти висновку, що чим менш імовірна ця подія, тим більше інформації. 
Інформація - будь-яке повідомлення, яке приймається, обробляється та розуміється [31].

Систему об'єкта та його атрибутів, що складаються 3 даних, що характеризуються деяким значенням у певний момент часу, можна назвати повідомленням. Інформацією можна назвати лише зміст, що передається повідомленням, тобто зрозумілий сенс (сенс) даних і співвідношення між ними [32].

Враховуючи зазначене ми визначаємо (Л. Коженовські), що інформація - це зміст, який передається повідомленням, що дозволяє зрозуміти сенс даних і взаємозв'язок між ними [33].

Наочно, інформацію можна характеризувати таким співідношенням (1).

$$
\mathbf{I}=\mathbf{K}\{\mathbf{P}, \mathbf{X}(\mathrm{x}), \mathrm{t}, \mathrm{q}\}
$$

де:

I - інформація,

К- повідомлення,

$\mathbf{P}$ - об'єкт, про який йдеться (його ідентифікатор),

$\mathbf{X}$ - атрибут (ознака) об'єкта $\mathbf{P}$,

$\mathbf{X}$ - значення атрибута $\mathbf{X}$,

$\mathrm{t}$ - час , коли $\mathbf{P}$ об'єкт $є \mathbf{X}$,

q - вектор додаткових характеристик, пов'язаних з об'єктом $\mathbf{P}$, атрибутом $\mathbf{X}$ (або) часом $\mathrm{t}$.

Інтерпретувати таке співвідношення можна таким чином, що Інформація (I) містить повідомлення $\mathbf{K}$, в якому повідомляється, що об'єкт $\mathbf{P}$ має значення $\mathbf{x}$ атрибута $\mathbf{X}$ в момент часу $\mathbf{t} 3$ додатковими характеристиками q. Даними $\epsilon$ елементи $\mathbf{P}, \mathbf{X}, \mathbf{x}, \mathbf{t}$.

На 22-й Всеукраїнській конференції рятувальників (за міжнародною участю), що була організована Інститутом державного управління та наукових досліджень 3 цивільного захисту у співпраці з Європейським інститутом безперервної освіти (Республіка Словакія), Інститутом менеджменту та безпеки Поморського університету (Республіка Польща), А. Скрабач, у своїй доповіді 3 питання функціонування екстренного номеру 112 в кризових ситуаціях наголосила на ключових засобах функціонування інтегрованої системи 
диспетчерського зв'язку, серед яких базісними є повідомлення, дзвінки та дані, що циркулюють між іiі організаційними та виконавчими суб'єктами (рис. 3). Також авторка звернула увагу на типологію обробки повідомлень у центрах кризового оповіщення (рис. 4), зазначивши, що за 2020 рік оброблено лише $34 \%$ обгрунтованих повідомлень [34]. Однак і ця інформація надала можливість системі антикризового менеджменту на достатньо високому рівні реагувати на кризові ситуації. Отже, одними 3 характеристик інформації $\epsilon$ iii своєчасність, обгрунтованість.

IНТЕГРОВАНА СИСТЕМА ДИСПЕТЧЕРСЬКОГО ЗВ'ЯЗКУ

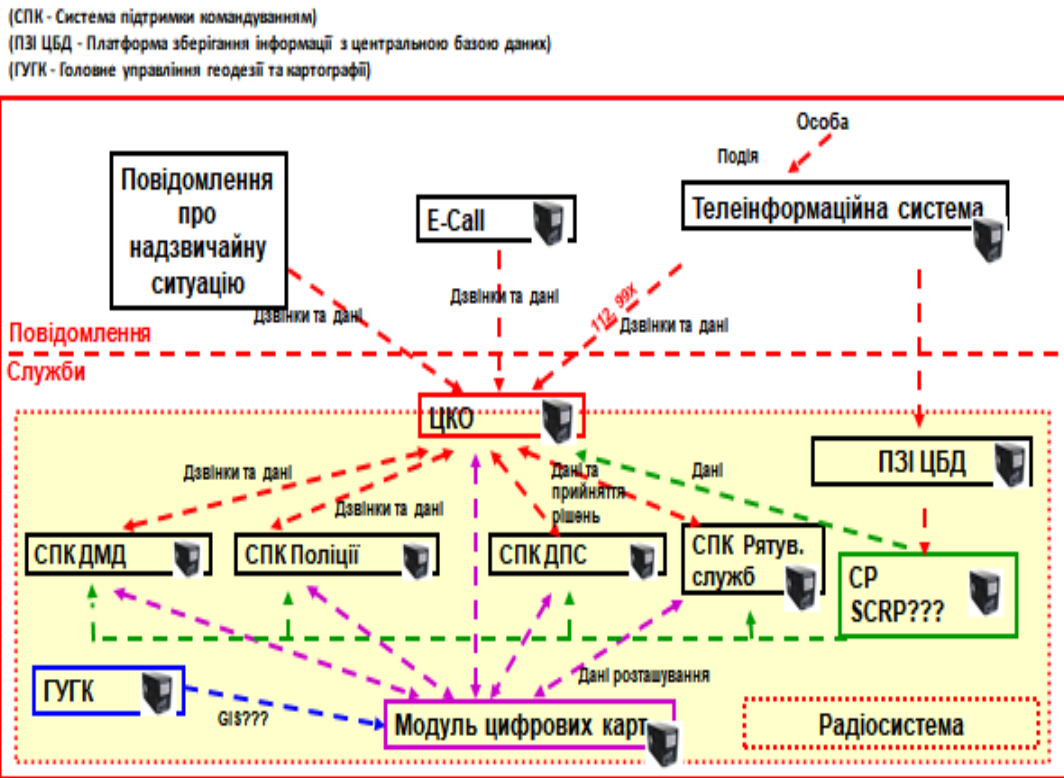

Рисунок 3 - Інформаційний потік в системі антикризового управління. 


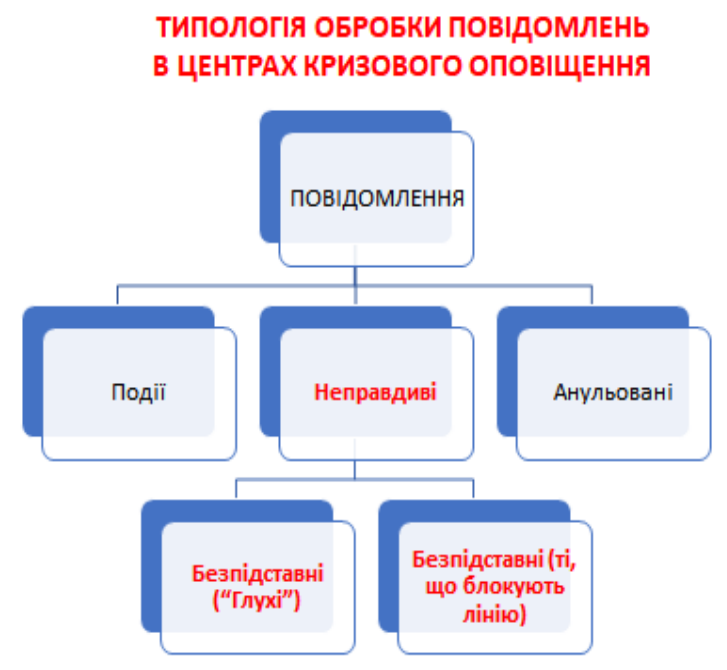

Рисунок 4 - Типологія обробки повідомлень в центрах кризового оповіщення Республіки Польща

Джерело: [34]

Із зазначеними характеристиками корелює поняття правдивості або хибності інформації (дезінформації). «Правда (істина) - це протилежне до того, що тільки здається, що існує» (Юзеф Тішнер) [цит. за 35, с. 45].

Істина - за класичним визначенням Аристотеля - це відповідність змісту фактичному стану речей. Для перевірки істинності прийняті такі критерії [36]:

інтуїтивний, що відносяться до «очевидності». $Є$, однак, випадки оптичних ілюзій, відзначені психологами що доводять неспроможність інтуїтивного критерію;

ситуаційній, до яких найчастіше відносять звичайність ситуації, в якій знаходиться спостерігач;

структурний, який розуміється як вибір і розташування слів, або посилання на повідомлення, які раніше вважалися істинними, що може бути використано для визначення істинності отриманого повідомлення (формальна логіка);

генетичний (експертний).

Хоча жодний із наведених критеріїв не може гарантувати істину, їх одночасне включення збільшує їі ймовірність. Отже, 
як правило, інформація, що є базисом важливих рішень, має надходити 3 декількох джерел i перевірятися за різними критеріями. Найефективнішим способом протидії хибності (дезінформації), зазначає Ярослав Кроплевський (Jarosław Kroplewski) є систематичне й ретельне спостереження та аналіз наданої інформації та іiі джерел [35]. Невипадково в планах антикризового менеджменту Республіки Польща (окремий розділ) приділяється увага організації моніторингу за визначеними загрозами для кожної території [37].

Логічний аналіз показує, що на істину впливають три основні фактори :

1. Реальність - як вона є, відомий об'єкт. Це ті аспекти фізичного всесвіту, які відомі людині. Тому реальність об'єктивна i обмежена тим, що можна сприйняти i, отже, виміряти.

Проте можна уявити ситуацію, коли змістом інформації $\epsilon$ спостереження про неіснуючу, уявну «реальність». В нашому випадку про ступінь ймовірності виникнення небезпеки.

2. Суб'єкт, що отримує інформацію. Одержувач повідомлення усвідомлює інформацію залежно від таких факторів, як [38]: час усвідомити; знання, які були раніше; контекст; емоційний стан одержувача; обставини отримання інформації; спосіб провадження.

Ці фактори важливі при підборі фахівців у координаційні центри, бо у процесі пізнання враження може бути одне, а сприйняття інше. Враження - це виявлення або безпосереднє переживання суб'єктом фізичної енергії, тоді як сприйняття це процес, за допомогою якого мозок обробляє та інтерпретує ці елементи в логічне ціле. I враховуючи це, як стверджують психологи сприйнята істинною інформація може бути обманом, брехнею або помилкою [30].

3. Фізичний простір, що розділяє реальність і суб'єкт, що пізнає, а також технічні засоби, що підтримують і водночас розривають безпосередній контакт спостерігача 3 об'єктом. Можливі спотворення істини залежать від типу носія та методів спостереження.

На роль інформації в управлінні впливає різноманітність іiі характеристик: інформація може бути об'єктивною чи 
суб'єктивною, потенційною чи активною, первинною чи вторинною. Серед значної кількості різноманітної інформації деяка може бути кориснішою, правильнішою, вигіднішою для користувачів, ніж інша, тобто вона буде якісно кращою.

Інформація може бути об'єктивною, що означає, що вона існує незалежно від одержувача. Ця особливість, зокрема, узгоджується 3 філософським поглядом, що інформація відображає різноманітність досліджуваного об'єкта. Це потенційний контент, який кожний користувач може інтерпретувати та використовувати відповідно до своїх суб'єктивних потреб і припущень. Таким чином, об'єктивна інформація також $є$ потенційною інформацією. Термін «об'єктивна інформація» означає лише те, що інформація не обтяжена суб'єктивним тлумаченням з боку одержувача. Однак воно обтяжене суб'єктністю, що випливає 3 конкретної, особистої точки зору відправника, який описує об'єкт у повідомленні. Повідомлення - це не система даних випадкової форми, а дані, навмисно відібрані відправником. Процес побудови повідомлення — це процес викриття точки зору відправника. Отже, це процес із явним суб'єктивним зарядом.

Однак прагматичний аспект вимагає врахування процесу отримання інформації ii користувачем [39]. Інформація, що міститься в повідомленні та отримана користувачем, стає, у прагматичному сенсі, суб’єктивною та залежною від одержувача.

Таким чином, інформація має подвійний характер об'єктивний і суб'єктивний водночас. Також можна розрізняти відповідно потенційну інформацію, корисну для когось невизначеного, і активну інформацію, корисну для конкретного користувача.

Інформація $є$ первинною, коли вона була отримана шляхом збору та обробки вхідних, оригінальних даних та інформація вторинна для певної мети. Вторинна інформація - це повторно використана первинна інформація, отримана раніше для інших цілей, певним чином оброблена.

Своєчасність інформації означає, що вона достатньо узгоджена за часом з реальним станом об'єкта. На зниження рівня актуальності впливає плин часу, що викликає зміну 
об'єкта, тобто з'являються нові, актуальні значення ознак, які є предметом інформації. Якщо в тій чи іншій ситуації різниця незначна, значить, інформація є актуальною, інакше інформація застаріла. Щоб дії були ефективними, необхідно вжити коригувальні дії до того, як відхилення від плану, норми або бажаного стану стане занадто великим. Отже, дані, повідомлення та інформація мають надходити до потрібної особи в потрібний час, щоб вона могла вжити правильних дій.

Враховуючи зазначене важливими показниками істинної корисної інформації є повнота, важливість, точність, гнучкість. Приховування важливої інформації при перебільшенні другорядних питань приводить до дезінформації керівного органу [35, с. 50].

Повнота, важливість інформації в системі антикризового менеджменту РП, як зазначалось вище, визначається сукупністю даних, що подається у відповідному звіті (початковому, уточнюючому, заключному) [24].

Точність інформації - це ступінь близькості отриманого фізичного розміру ознаки до фактичної величини. Нам не відома фактична величина, ми знаємо лише більш-менш точний результат вимірювання, більший чи менший ступінь відповідності реальному об'єкту. Отже, точність відносна, залежить від очікувань одержувача, прийнятої міри та методики вимірювання.

Інформаційна гнучкість означає здатність задовольняти сьогодняшні та майбутні потреби різних користувачів. Це залежить від методу агрегації (тобто групування), рівня узагальнення, способу обміну та своєчасності інформації. Індивідуальна інформація $\epsilon$ найбільш гнучкою, оскільки іiі можуть використовувати різні користувачі та для різних цілей.

Достовірність інформації складається 3 об'єктивності та коректності в підготовці даних і отриманні повідомлення, зміст якого становить інформацію. Достовірність інформації може бути знижена як шляхом доповнення інформації в очікуваному одержувачем напрямку, так і шляхом пропуску певних даних. Характеризуючи достовірність інформації, слід описати причини, чому інформація має або не має бажаних характеристик. 
Цінність інформації $є$ зворотною від загальновідомої ймовірності події, до якої ця інформація належить. Якщо $є$ впевненість (тобто ймовірність того, що дана подія дорівнює 1 , або якщо повідомлення не усуває невизначеності, то повідомлення не має значення. Однак таке повідомлення важливе, оскільки надає можливість підтвердити свої знання.

Інформаційна достатність означає такі властивості, які дають можливість раціонально діяти (ухвалити рішення). Більш широке поняття - це повнота інформації, тобто набір інформації, що належить до підмножини інформаційного потоку, але через витрати та час повнота інформації не завжди є найважливішою ознакою. Керівники часто завалені нерелевантною та марною інформацією. Якщо вони отримають більше інформації, ніж вони можуть ефективно використати, вони можуть пропустити інформацію, яка стосується серйозних проблем. У даному випадку раціональною дією $є$ ігнорування деяких даних і заміна їх досвідом, інтуїцією, переконанням. Інакше можна зіткнутися 3 надлимковістю інформації. «Надлишковість — це відсоток даних, які не є суттєвими, але це ще не означає, що вони марні» [40].

Ще однією характеристикою інформації $\epsilon$ унікальність інформації. Ідентифікатор об'єкта, специфікація атрибута, одиниці вимірювання, часу та додаткових характеристик запобігають змішування 3 іншим об'єктом, атрибутом, одиницею тощо. Поліпшенню однозначності сприяють мовні норми та стандарти, а також номенклатури та класифікації.

Висновки та напрями подальших досліджень. «Інформація»є основою ухвалення державних управлінських рішень, невід'ємною частиною системи, метою якої $\epsilon$ зменшення стану невизначеності її функціонування. Це не лише міждисциплінарний термін, який протилежить невідомому, а й ключовий фактор (важіль державного управління) національної безпеки та її складової - цивільної безпеки.

Обіг інформації (інформаційний потік) $є$ основою належного функціонування системи антикризового управління Республіки Польща.

Аналіз системи антикризового менеджменту Республіки Польща свідчить, що діяльність органів управління спрямована 
на організацію і підтримку всіх можливих систем комунікації інформаційних, транспортних, логістичних тощо.

Координація органів управління (сил) антикризового менеджменту заснована на базі отримання (надання) повідомлень (інформації) з наявних сил і засобів та проведених заходах суб'єкта системи нижнього рівня управління та повідомлень із запитом необхідних сил і засобів 3 вищих рівнів управління.

Пропонується замість поняття «моніторинг» ввести поняття «контролінг», в основі якого лежить збір, обробка, перевірка, стандартизація відповідної інформації (повідомлення) про стан (загрозу, ризик) об’єкта захисту.

Для упорядкування ієрархічної інформації та обробки даних в системі антикризового менеджменту РП, підтримання ефективного інформаційного потоку стандартизованих даних (збір мінімального обсягу даних, доповнення (за необхідності) їх додатковою інформацією та представленні у вигляді звіту (початкового, корегуючого, заключного) про ситуацію) функціонує інформаційно-аналітична система «Central Reporting Application».

Інформація - це зміст, який передається повідомленням, що дозволяє зрозуміти сенс даних і взаємозв'язок між ними, точка опори системи (механізму) державного управління антикризового менеджменту, відповідно до характеристик якої визначається ефективність діяльності його комунікаційної складової, зокрема, та всієї системи антикризового менеджменту загалом.

Значущими характеристиками інформації $є$ актуальність, цінність, своєчасність, обгрунтованість, правдивість або істинність (хибність), суб'єктність (суб'єктивність), об'єктивність, первинність (вторинність), корисність, повнота, точність, гнучкість, достовірність, достатність, унікальність, однозначність.

Напрямом подальшого дослідження є вивчення практичних кейсів щодо функціонування інформаційно-аналітичних систем антикризового менеджменту країн Європи 3 визначення значущих характеристик інформаційних потоків, що в них обробляються, врахування їх при стандартизації інформаційних 


\title{
Науковий вісник : Державне управління № 4(10) 2021
}

\author{
звітів, які $\epsilon$ основою, наприклад, планування в системі \\ антикризового управління Республіки Польща.
}

\section{Список використаних джерел}

1. Тихомиров Д. О. Теоретико-правові засади державної політики у сфері цивільної безпеки в Україні. Дис. ... док. юридич. наук : 12.00.01. Національна академія внутрішніх справ Міністерства внутрішніх справ України, Київ, 2021. 506 с.

2. Борисов А. В., Литвиновський С. Ю. Антикризовий менеджмент у республіці Польща: огляд основного закону та практик його застосування на територіальному рівні державного управління. Науковий вісник : Державне управління. 2021. №2 (8). DOI: https://doi.org/10.32689/2618-0065-2021-2(8)-56-91 (дата звернення : 01.11.2021).

3. Мельниченко О. А. Механізми публічного управління реагуванням на надзвичайні ситуації: сутність та види. Науковий вісник : Державне управління. 2020. № 3(5). DOI: https://doi.org/10.32689/2618-0065-2020-3(5)-165-176 (дата звернення : 01.11.2021).

4. Волянський П. Б., Гур`єв С. О., Соловйов О. С., Терент`єва А. В. Кризовий менеджмент і принципи управління ризиками в процесі ліквідації наслідків надзвичайних ситуацій : монографія. Вид. 2 виправ. та доп. К.: Парлам. вид-во, 2021. 432 с.

5. Бакуменко В. Д. Теоретико-методологічні засади формування державно-управлінських рішень: Автореф. дис. ... док. держ. упр. УАДУ при Президентові України. 2001. 35 с.

6. Федорчак О. Класифікація механізмів державного управління. Науковий вісник «Демократичне врядування». 2018. Вип. 1. URL : http://lvivacademy.com/vidavnitstvo_1/visnik/fail/O_Fedorchak.pdf (дата звернення : 03.11.2021).

7. Засунько С. С. Місце та роль державного управління у системі забезпечення цивільного захисту в Україні. Науковий вісник Львівського держсавного університету внутрішніх $\begin{array}{lllll}\text { справ. } 2011 . & \text { №3. } & \text { C. }\end{array}$ https://www.lvduvs.edu.ua/en/documents_pdf/visnyky/nvsy/03_2011/11zsszvu.pdf (дата звернення 29.10.2021)

8. Гаман П. І. Роль державного управління у системі забезпечення цивільного захисту в Україні. Науковий вісник : Державне управління. 2018. № 1. С. 25-33. DOI: https://doi.org/10.32689/2618-0065-2018-1/1-25-33 (дата звернення 29.10.2021).

9. Механізм держ. упр. / Національна бібліотека імені В. I. Вернадського : Вебсайт. URL : http://www.irbis-nbuv.gov.ua/cgi-bin/irbis_nbuv/cgiirbis_64.exe (дата звернення 25.10.2021).

10. Барило О. Г. Аналіз визначень поняття «механізми державного управління» та його уточнення для сфери цивільного захисту. Інвестиції: практика та досвід. 2018. № 1. С. $63-$ 69. URL : http://nbuv.gov.ua/UJRN/ipd_2018_1_14 (дата звернення : 25.10.2021).

11. Потеряйко C. П. Дослідження стану категорійно-понятійного апарату механізмів державного управління у сфері цивільного захисту. Актуальні проблеми державного управління. 2017. № 2. С. 59-65. URL : http://nbuv.gov.ua/UJRN/apdy_2017_2_10 (дата звернення : 25.10.2021).

12. Андреєв С. О. Організаційно-правовий механізм державного управління цивільним захистом на регіональному рівні: автореф. дис. ... канд. держ. упр.: 25.00.02. Харків, 2010. 19 с.

13. Майстро С. В., Труш О. О. Нормативно-правовий механізм державного управління системою цивільного захисту в Україні. Актуальні проблеми державного управління. 2014. № 2. C. 156-162. URL : http://nbuv.gov.ua/UJRN/apdy_2014_2_22 (дата звернення : 25.10.2021).

14. Харламова Ю. Є. Особливості функціонування організаційного механізму державного управління у сфері підготовки фахівців служби цивільного захисту. Університетські 


\section{Науковий вісник : Державне управління № 4(10) 2021}

наукові записки. 2015. № 1. С. 312-319. URL : http://nbuv.gov.ua/UJRN/Unzap_2015_1_33 (дата звернення : 25.10.2021).

15. Потеряйко С. П. Проблемні питання щодо функціонування організаційного та структурного механізмів державного управління у сфері цивільного захисту. Вісник Національного університету иивільного захисту Украӥни. Серія : Державне управління. 2017. Вип. 2. С. 415-423. URL : http://nbuv.gov.ua/UJRN/VNUCZUDU_2017_2_54 (дата звернення : 25.10.2021)

16. Усик С. Дослідження правового механізму забезпечення інформаційної безпеки в умовах надзвичайних ситуацій. Науковий вісник : Державне управління. 2020. №4(6). URL : https://nvdu.undicz.org.ua/index.php/nvdu/article/view/135 (дата звернення : 25.10.2021).

17. Подобєд I. Нормативно-правове забезпечення розвитку матеріально-технічного потенціалу єдиної державної системи цивільного захисту. Науковий вісник : Державне управління. 2021. № 1 (7). URL : https://nvdu.undicz.org.ua/index.php/nvdu/article/view/155 (дата звернення : 25.10.2021).

18. Сіцинська М. В., Борисов А. В. Структура механізмів державного управління: сутність та методичний підхід до їі формування. Науковий вісник : Держсавне управління. № 1. 2018. URL : https://nvdu.undicz.org.ua/index.php/nvdu/article/view/16/13 (дата звернення 20.10.2021).

19. Барило О. Г. Інформація як складова системи державного управління у надзвичайних ситуаціях. Інвестииії: практика та досвід. 2011. № 2, 76-78. URL : $\mathrm{http}: / /$ www.investplan.com.ua/?op=1\&z=1018\&i=17 (дата звернення : 25.10.2021).

20. Теоретико-методологічні засади функціонування та розвитку системи інформаційноаналітичного забезпечення цивільного захисту України. Дис. ... док. наук держ. упр.: 25.00.02. МАУП., $2021 . \quad 504 \quad$ c. https://drive.google.com/file/d/1tPRA_11zRPpCaloBatzgn7AInEuVnpxm/view (дата звернення 01.11.2021).

21. Ситник Г. П. Державне управління у сфері національної безпеки (концептуальні та організаційні засади) : підручник. Київ, 2012. 544 с.

22. Про інформацію : Закон України № № 2657-XII від 02 жовтня 1992 (із змінами). // База даних «Законодавство України» / BP України. URL : https://zakon.rada.gov.ua/laws/show/2657-12\#Tеxt (дата звернення : 03.11.2021).

23. Mateusz Jurgiewicz Obieg informacji w ramach systemu zarządzania kryzysowego w gminie, powiecie i województwie. Nowa strategia. Sty 26. 2016. URL : http://www.nowastrategia.org.pl/obieg-informacji-w-ramach-systemu-zarzadzania-kryzysowegow-gminie-powiecie-i-wojewodztwie/ (дата звернення : 03. 10.2021).

24. Kamil Galicki, Grzegorz Świszcz Usprawnienie procesu obiegu informacji w systemie zarządzania kryzysowego. Przegląd bezpieczeństwa wewnętrznego. WARSZAWA. 2013. № 9 (5). URL : https://docplayer.pl/1580347-Przeglad-bezpieczenstwa-wewnetrznego.html (дата звернення : 25.10.2021).

25. Markowski A.: Kultura języka polskiego. Teoria. Zagadnienia leksykalne. PWN, 2018. 378 s.

26. Korzeniowski L. F.: Podstawy zarządzania organizacjami. Wyd. 2. Warszawa : Difin. 2019. 335 s.

27. ISO 8402 : 1996. Zarządzanie jakością i zapewnienie jakości. Terminologia. Polska Norma PN. PKN. 1996. $43 \mathrm{~s}$.

28. Академічний тлумачний словник української мови. URL : http://sum.in.ua/s/vazhilj (дата звернення 03.11.2021).

29. Kieżun W.: Sprawne zarządzanie organizacją. Warszawa: SGH. 1997. 349 s.

30. Zieliński T. Informacja w procesie oceny banku. Bank. 1999, № 8, s. 40.

31. Reber A. S.: Słownik psychologii. Warszawa: SCHOLAR. 2002. s. 267.

32. Tomaszewski T. Główne idee współczesnej psychologii. Warszawa: Wiedza Powszechna, 1986. s. 166.

33. Korzeniowski L. F: Podstawy nauk o bezpieczeństwie. Wydanie II. Warszawa: Difin, 2017. s. 95.

34. Skrabacz A. Functioning of the emergency number 112 in crisis situations. IPA\&R\&PP : web-sait. URL : https://cutt.ly/rR8jXDq (дата звернення : 04.11.2021). 


\section{Науковий вісник : Державне управління № 4(10) 2021}

35. Zagadnienia bezpieczeństwa - wieloaspektowość / Red. Nauk. Sommer H., Zakrzewski G. URL : https://cutt.ly/PR8jA5V (дата звернення 25.10.2021).

36. Kotarbiński T. Elementy teorii poznania, logiki formalnej i metodologii nauk. Warszawa: PWN, 1986, s. 118.

37. Wojewódzki plan zarządzania kryzysowego (część b) / Pomorski Urzad Wojewodzki w Gdansku. Retrieved from https://cutt.ly/MbX5gg1 [in Poland].

38. Stefanowicz B. Informacja. Warszawa: SGH, 2004, s. 20-21.

39. Stefanowicz B. Wybrane zagadnienia infologicznej analizy informacji. Płock: NOVUM, 1999, s. 14.

40. Peciak J. O utajnianiu mowy bez tajemnic. Warszawa: MON 1980, s. 21.

41. Твердохліб О. С. Етичні аспекти доступу до публічної інформації. Економіка та держава. 2013. № 6. C. 110-112.

\section{References}

1. Tykhomyrov D. O. (2021) Teoretyko-pravovi zasady derzhavnoi polityky u sferi tsyvilnoi bezpeky v Ukraini [Theoretical and legal principles of state policy in the field of civil security in Ukraine.] Doctor's thesis. Kyiv [in Ukrainian].

2. Borysov A. V., Lytvynovskyi Ye. Yu. (2021) Antykryzovyi menedzhment u respublitsi Polshcha: ohliad osnovnoho zakonu ta praktyk yoho zastosuvannia na terytorialnomu rivni derzhavnoho upravlinnia [Crisis management in the Republic of Poland: a review of the basic law and practices of its application at the territorial level of public administration]. Naukovyi visnyk : Derzhavne upravlinnia. №2 (8). DOI: https://doi.org/10.32689/2618-0065-2021-2(8)-56-91 [in Ukrainian].

3. Melnychenko O. A. (2020) Mekhanizmy publichnoho upravlinnia reahuvanniam na nadzvychaini sytuatsii: sutnist ta vydy. Naukovyi visnyk : Derzhavne upravlinnia. № 3(5). DOI: https://doi.org/10.32689/2618-0065-2020-3(5)-165-176 [in Ukrainian].

4. Volianskyi P. B., Hur iev C. O., Soloviov O. S., Terent ieva A. V. (2021) Kryzovyi menedzhment i pryntsypy upravlinnia ryzykamy $\mathrm{v}$ protsesi likvidatsii naslidkiv nadzvychainykh sytuatsii : monohrafiia. Vyd. 2 vyprav. ta dop. K.: Parlam. vyd-vo. 432 s. [in Ukrainian].

5. Bakumenko V. D. (2001) Teoretyko-metodolohichni zasady formuvannia derzhavno-upravlinskykh rishen [Theoretical and methodological principles of formation of public administration decisions]. Extended abstract of Doctor's thesis. $35 \mathrm{~s}$. [in Ukrainian].

6. Fedorchak O. (2018) Klasyfikatsiia mekhanizmiv derzhavnoho upravlinnia [Classification of public administration mechanisms]. Naukovyi visnyk «Demokratychne vriaduvannia». Vyp. 1. Retrieved from http://lvivacademy.com/vidavnitstvo_1/visnik/fail/O_Fedorchak.pdf [in Ukrainian].

7. Zasunko S. S. (2011) Mistse ta rol derzhavnoho upravlinnia u systemi zabezpechennia tsyvilnoho zakhystu v Ukraini [The place and role of public administration in the system of civil protection in Ukraine]. Naukovyi visnyk Lvivskoho derzhavnoho universytetu vnutrishnikh sprav. №3. S. 101111. Retrieved from https://cutt.ly/zR8vgXd [in Ukrainian].

8. Haman P. I. (2018) Rol derzhavnoho upravlinnia u systemi zabezpechennia tsyvilnoho zakhystu v Ukraini [The role of public administration in the system of civil protection in Ukraine]. Naukovyi visnyk : Derzhavne upravlinnia. № 1. S. 25-33. DOI: https://doi.org/10.32689/2618-0065-20181/1-25-33 [in Ukrainian].

9. Mekhanizm derzh. upr. [Mechanism of public administration] / Natsionalna biblioteka imeni V. I. Vernadskoho : Vebsait. Retrieved from : http://www.irbis-nbuv.gov.ua/cgibin/irbis_nbuv/cgiirbis_64.exe [in Ukrainian].

10. Barylo O. H. (2018) Analiz vyznachen poniattia «mekhanizmy derzhavnoho upravlinnia» ta yoho utochnennia dlia sfery tsyvilnoho zakhystu [Analysis of definitions of the concept of "mechanisms of public administration" and its clarification for the field of civil protection]. Investytsii: praktyka ta dosvid. № 1. S. 63-69. Retrieved from : http://nbuv.gov.ua/UJRN/ipd_2018_1_14 [in Ukrainian]. 


\section{Науковий вісник : Державне управління № 4(10) 2021}

11. Poteriaiko S. P. (2017) Doslidzhennia stanu katehoriino-poniatiinoho aparatu mekhanizmiv derzhavnoho upravlinnia u sferi tsyvilnoho zakhystu [Research of the state of the categoricalconceptual apparatus of the mechanisms of public administration in the field of civil protection]. Aktualni problemy derzhavnoho upravlinnia. № 2. S. 59-65. Retrieved from : http://nbuv.gov.ua/UJRN/apdy_2017_2_10 [in Ukrainian].

12. Andreiev S. O. (2010) Orhanizatsiino-pravovyi mekhanizm derzhavnoho upravlinnia tsyvilnym zakhystom na rehionalnomu rivni [Organizational and legal mechanism of state management of civil protection at the regional level]. Extended abstract of Candidate's thesis. Kharkiv. 19 s. [in Ukrainian].

13. Maistro S. V., Trush O. O. (2014) Normatyvno-pravovyi mekhanizm derzhavnoho upravlinnia systemoiu tsyvilnoho zakhystu v Ukraini [Regulatory and legal mechanism of state management of the civil protection system in Ukraine]. Aktualni problemy derzhavnoho upravlinnia. № 2. S. 156-162. Retrieved : http://nbuv.gov.ua/UJRN/apdy_2014_2_22 [in Ukrainian].

14. Kharlamova Yu. Ye. (2015) Osoblyvosti funktsionuvannia orhanizatsiinoho mekhanizmu derzhavnoho upravlinnia u sferi pidhotovky fakhivtsiv sluzhby tsyvilnoho zakhystu [Peculiarities of functioning of the organizational mechanism of public administration in the field of training of specialists of the civil protection service]. Universytetski naukovi zapysky. № 1. S. 312-319. Retrieved from : http://nbuv.gov.ua/UJRN/Unzap_2015_1_33 [in Ukrainian].

15. Poteriaiko S. P. (2017) Problemni pytannia shchodo funktsionuvannia orhanizatsiinoho ta strukturnoho mekhanizmiv derzhavnoho upravlinnia u sferi tsyvilnoho zakhystu [Problematic issues regarding the functioning of organizational and structural mechanisms of public administration in the field of civil protection]. Visnyk Natsionalnoho universytetu tsyvilnoho zakhystu Ukrainy. Seriia : Derzhavne upravlinnia. Vyp. 2. S. 415-423. Retrieved from : http://nbuv.gov.ua/UJRN/VNUCZUDU_2017_2_54 [in Ukrainian].

16. Usyk S. (2020) Doslidzhennia pravovoho mekhanizmu zabezpechennia informatsiinoi bezpeky v umovakh nadzvychainykh sytuatsii [Research of the legal mechanism of providing information security in the conditions of emergency situations]. Naukovyi visnyk : Derzhavne upravlinnia. №4(6). Retrieved from : https://nvdu.undicz.org.ua/index.php/nvdu/article/view/135 [in Ukrainian].

17. Podobied I. (2021) Normatyvno-pravove zabezpechennia rozvytku materialno-tekhnichnoho potentsialu yedynoi derzhavnoi systemy tsyvilnoho zakhystu [Regulatory and legal support for the development of material and technical potential of the unified state system of civil protection]. Naukovyi visnyk : Derzhavne upravlinnia. № 1 (7). Retrieved from : https://nvdu.undicz.org.ua/index.php/nvdu/article/view/155 [in Ukrainian].

18. Sitsynska M. V., Borysov A. V. (2018) Struktura mekhanizmiv derzhavnoho upravlinnia: sutnist ta metodychnyi pidkhid do yii formuvannia [The structure of mechanisms of public administration: the essence and methodological approach to its formation]. Naukovyi visnyk : Derzhavne upravlinnia. № 1. Retrieved from : https://nvdu.undicz.org.ua/index.php/nvdu/article/view/16/13 [in Ukrainian].

19. Barylo O. H. (2011) Informatsiia yak skladova systemy derzhavnoho upravlinnia u nadzvychainykh sytuatsiiakh [Information as a component of the system of public administration in emergency situations]. Investytsii: praktyka ta dosvid. № 2, 76-78. Retrieved from : http://www.investplan.com.ua/?op=1\&z=1018\&i=17 [in Ukrainian].

20. Barylo O. H. (2021) Teoretyko-metodolohichni zasady funktsionuvannia ta rozvytku systemy informatsiino-analitychnoho zabezpechennia tsyvilnoho zakhystu Ukrainy. Doctor's thesis. MAUP. $\quad 504 \quad$ s. $\quad$ Retrieved from https://drive.google.com/file/d/1tPRA_11zRPpCaloBatzgn7AInEuVnpxm/view [in Ukrainian]. 


\section{Науковий вісник : Державне управління № 4(10) 2021}

21. Cytnyk H. P. (2012) Derzhavne upravlinnia u sferi natsionalnoi bezpeky (kontseptualni ta orhanizatsiini zasady) [Public administration in the field of national security (conceptual and organizational principles)]: pidruchnyk. Kyiv, 544 s. [in Ukrainian].

22. Zakon Ukrainy Pro informatsiiu vid 02 zhovtnia 1992 № 2657-XII (iz zminamy) [About information: Law of Ukraine]. // Baza danykh «Zakonodavstvo Ukrainy» / VR Ukrainy. Retrieved from : https://zakon.rada.gov.ua/laws/show/2657-12\#Text [in Ukrainian].

23. Mateusz Jurgiewicz (2016) Obieg informacji w ramach systemu zarządzania kryzysowego w gminie, powiecie i województwie [Information flow within the crisis management system in the commune, poviat and voivodship]. Nowa strategia. Sty 26 URL : http://www.nowastrategia.org.pl/obieg-informacji-w-ramach-systemu-zarzadzania-kryzysowegow-gminie-powiecie-i-wojewodztwie/ [in Polish].

24. Kamil Galicki, Grzegorz Świszcz Usprawnienie procesu obiegu informacji w systemie zarządzania kryzysowego [Improving the information flow process in the crisis management system.]. Przeglad bezpieczeństwa wewnętrznego. WARSZAWA. 2013. № 9 (5). Retrieved from https://docplayer.pl/1580347-Przeglad-bezpieczenstwa-wewnetrznego.html [in Polish].

25. Markowski A. (2018) Kultura języka polskiego. Teoria. Zagadnienia leksykalne [Culture of the Polish language. Theory. Lexical issues.]. PWN. 378 s. [in Polish].

26. Korzeniowski L. F. (2019) Podstawy zarządzania organizacjami [Fundamentals of organization management.]. Wyd. 2. Warszawa : Difin. 2019. 335 s. [in Polish].

27. ISO 8402 : 1996. (1996) Zarządzanie jakością i zapewnienie jakości. Terminologia. [Quality management and quality assurance. Terminology]. Polska Norma PN. PKN, 43 s. [in Polish].

28. Akademichnyi tlumachnyi slovnyk ukrainskoi movy [Academic explanatory dictionary of the Ukrainian language]. Retrieved from : http://sum.in.ua/s/vazhilj [in Ukrainian].

29. Kieżun W. (1997) Sprawne zarządzanie organizacją [Efficient management of the organization]. Warszawa: SGH. 349 s. [in Polish].

30. Zieliński T. (1999) Informacja w procesie oceny banku [Information in the bank assessment process]. Bank. № 8, s. 40. [in Polish].

31. Reber A. S. (2002) Słownik psychologii [Dictionary of Psychology]. Warszawa: SCHOLAR. s. 267. [in Polish].

32. Tomaszewski T. (1986) Główne idee współczesnej psychologii [The main ideas of modern psychology]. Warszawa: Wiedza Powszechna, s. 166. [in Polish].

33. Korzeniowski L. F (2017) Podstawy nauk o bezpieczeństwie [Fundamentals of security sciences]. Wydanie II. Warszawa: Difin, s. 95. [in Polish].

34. Skrabacz A. Functioning of the emergency number 112 in crisis situations. IPA\&R\&PP : web-sait. Retrieved from https://cutt.ly/rR8jXDq [in Ukrainian].

35. Zagadnienia bezpieczeństwa - wieloaspektowość [Security issues - multi-faceted nature] / Red. Nauk. Sommer H., Zakrzewski Retrieved from : https://cutt.ly/PR8jA5V [in Polish].

36. Kotarbiński T. Elementy teorii poznania, logiki formalnej i metodologii nauk [Elements of the theory of knowledge, formal logic and methodology of science]. Warszawa: PWN, 1986, s. 118 [in Polish].

37. Wojewódzki plan zarządzania kryzysowego (część b) [Local crisis management plan] / Pomorski Urzad Wojewodzki w Gdansku. Retrieved from https://cutt.ly/MbX5gg1 [in Polish].

38. Stefanowicz B. Informacja [Information]. Warszawa: SGH, 2004, s. 20-21 [in Polish].

39. Stefanowicz B. Wybrane zagadnienia infologicznej analizy informacji [Selected commands for infological analysis of information]. Płock: NOVUM, 1999, s. 14. [in Polish].

40. Peciak J. O utajnianiu mowy bez tajemnic [About the secret language without secrets]. Warszawa: MON 1980, s. 21 [in Polish].

41. Tverdokhlib O. S. Etychni aspekty dostupu do publichnoi informatsii. [Ethical aspects of access to public information]. Ekonomika ta derzhava. 2013. № 6. S. 110-112 [in Ukrainian]. 


\title{
INFORMATION - BASIC LEVER OF ANTI-CRISIS MANAGEMENT OF THE REPUBLIC OF POLAND
}

\author{
Leszek F. Korzeniowski, Yevhen Lytvynovskyi
}

\begin{abstract}
The requirements of modernity, the functioning of global society in the face of extraordinary challenges to its sustainability draws attention to methodological and scientific research on civil security, the study of best practices in crisis management in Europe. Also, the scientific task is a theoretical justification of the components of the mechanism of public administration in the field of civil security and their characteristics. Based on the analysis of the mechanism of state anti-crisis management of the Republic of Poland, information is hypothetically defined as its central (basic) lever, its significant characteristics are substantiated. The research methods were the method of comparative analysis, content analysis, hypothetical method, method of interviewing experts. Based on the analysis of previous studies, it is determined that such structural elements of the mechanism of public administration as policies, levers, tools, in particular in the management of civil security, have not found their place, in some studies are identified, and in many studies they are mentioned. These studies are the theoretical basis for confirming the hypothesis that "information" is the basis of public administration decisions, an integral part of the system, which aims to reduce the uncertainty of its operation, not only an interdisciplinary term that contradicts the unknown, but also a key factor management) of national security, the circulation of information is the basis for the proper functioning of the anti-crisis management system of the Republic of Poland. Analysis of the anti-crisis management system of the Republic of Poland shows that the activities of government agencies are aimed at organizing and supporting all possible communication systems information, transport, logistics and more. And the higher the level of management, the more important is the factor of coordination of certain activities. This coordination of management bodies (forces) of anti-crisis management is based on receiving (providing) messages (information) from available forces and means and activities of the subject of the lower level management system and messages requesting the necessary forces and means from higher levels. Much attention is also paid to the system of monitoring identified threats. It is proposed to replace the concept of "monitoring" with the concept of "controlling", which is based on the collection, processing, verification, standardization of relevant information (messages) about the state (threat, risk) of the object of protection. It is determined that in order to organize hierarchical information and data processing in the RP crisis management system, maintain an effective information flow of standardized data (collection of the minimum amount of data, supplement (if necessary) their additional information and present in the form of a report (initial, corrective, final) ) the informationanalytical system "Central Reporting Application" functions. It is concluded that information is the content transmitted by the message, which allows to understand the meaning of data and the relationship between them, the fulcrum of the system (mechanism) of public administration of crisis management, according to the characteristics of which determines the effectiveness of its communication component, in particular, and the entire crisis management system as a whole. Significant characteristics of information are identified and described, including relevance, value, timeliness, validity, truthfulness or truth (falsity), subjectivity (subjectivity), objectivity, primacy (secondary), usefulness, completeness, accuracy, flexibility, reliability, sufficiency, uniqueness, unambiguity. The direction of further research is to study practical cases on the functioning of information and analytical systems of crisis management in Europe to determine the significant characteristics of information flows that are processed in them.
\end{abstract}

Key words: civil security, mechanism of public administration, system of anti-crisis management of the Republic of Poland, information, lever. 